\title{
Peran Komunitas Seni Budaya dalam Pembentukan City Branding
}

\author{
Pupung Zulyan a,1,*, Sri Dewi Setiawati ${ }^{\mathrm{b}, \mathrm{c}, 2}$ \\ ${ }^{a, b}$ Ars University, Antapani, Jl. Terusan Sekolah No.1-2, Kota Bandung, Jawa Barat, Indonesia 40282 \\ ${ }^{1}$ zulyan6@gmail.com*; ${ }^{2}$ sds.sridewi@gmail.com; \\ * corresponding author
}

\section{ABSTRACT}

Article history:

Received: September 15, 2020

Reviewed: October 23, 2020

Accepted: November 16, 2020

Published: December 21, 2020

Keyword: Community, Traditional Art and Culture, City Branding

Kata kunci: Komunitas, Seni dan Budaya Tradisional, City branding
This research aims to find out what efforts are made by the Kitchen community of art and culture of Bandung to help form City Branding. Community. Bandung's art and cultural kitchen is a community that does traditional Sundanese art and culture through tourism. The activities carried out by the community Kitchen arts and culture are expected to not only preserve traditional arts and culture, but also preserve nature and improve the economy of the surrounding community. The role of The Kitchen Arts and Culture Community in the establishment of city branding bandung city by becoming one of the icons of Bandung City. Starting from the preservation of traditional arts and culture that they do as a characteristic formation for the deference of marketing of traditional arts and cultures that originate from their area through tourism activities and become ambassadors representing the city of Bandung to several cities in Indonesia. For the role of the government in the establishment of city branding, it is necessary to align the objectives between the previous officials and the new officials, so that the goals made can be realized to the maximum, because often occurs when the shift in the position of existing programs needs to be re-socialized from the beginning.

\begin{abstract}
ABSTRAK
Penelitian ini bertujuan untuk mengetahui upaya apa saja yang dilakukan oleh komunitas Dapur seni dan budaya Kota Bandung untuk membantu pembentuk City Branding. Komunitas Dapur seni dan budaya Kota Bandung merupakan komunitas yang melakukan pelestarian seni dan budaya tradisional sunda melalui pariwisata. Kegiatan -kegiatan yang di lakukan oleh komunitas Dapur seni dan budaya di harapkan tidak hanya melestarikan seni dan budaya tradisional saja, tetapi juga menjaga alam dan meningkatkan perekonomian masyarakat sekitar. Peran Komunitas Dapur Seni dan Budaya dalam pembentukan city branding Kota Bandung dengan menjadi salah satu ikon Kota Bandung dengan membentukan ciri khas sebagai diferensiasi dalam kesenian budaya tradisional yang lahir dari tempat mereka berasal yang selanjutnya dipasarkan melalui kegiatan pariwisata dan membawa seni dan budaya tradisional tersebut dengan menjadi perwakilan Kota Bandung sebagai duta kebeberapa kota di luar Provinsi Jawa Barat. Dan peran pemerintah dalam pembentukan city branding dirasa masih belum optimal karena dipelukannya keselarasan tujuan antara pejabat sebelumnya dengan pejabat baru saat pergantian jabatan, agar tujuan yang dibuat dapat terwujudkan dengan maksimal, karena sering terjadi disaat pergeseran jabatan program-program yang sudah ada perlu disosialisasikan kembali.
\end{abstract}

Copyright $\odot 2019$ Politeknik Negeri Samarinda. All rights reserved. 


\section{Pendahuluan}

Dapur Seni dan Budaya (DAPSENBUD) Kota Bandung adalah sebuah komunitas (organisasi sosial) yang terbentuk pada tahun 2006, dengan kesamaan latar belakang dan tujuan untuk melakukan pelestarian seni dan budaya tradisional agar tetap bertahan. Mengarah kepada pemberdayaan komunitas dimana mereka berusaha meningkatkan usaha atau kemampuan komunitas dalam memecahkan berbagai macam permasalahan sebagai upaya mereka beradaptasi dari perubahan sosial dan demi meningkatan kualitas hidup, sebagai cara mereka mewujudkan kemandirian juga kesejahteraan melalui pemanfaatan seni budaya tradisional.

Komunitas DAPSENBUD yang beranggotakan berupa kelompok/grup pada tahun 2015 sudah memiliki anggota sebanyak 32 kelompok/grup dengan 469 pelaku seni, dari 14 jenis kesenian budaya tradisional. Dan di tahun 2020 anggota komunitas DAPSENBUD kurang lebih mencapai 80 kelompok/grup yang tidak hanya berasal dari daerah Bandung Timur bergabung menjadi bagian dari Komunitas DAPSENBUD.

Berangkat dari kepedulian terhadap potensi yang dimiliki oleh masyarakat sekitar di kawasan Sentra Wisata Terpadu Manglayang dan melihat adanya kesempatan besar untuk memperkenalkan seni budaya tradisional yang ada di daerah Cibiru dalam upaya pelestarian, Komunitas DAPSENBUD pada tahun 2010 akhirnya memutuskan untuk melakukan suatu acara pagelaran seni budaya tradisional yang diberi nama "Pentas Seni Budaya" dari hasil patungan/iuran para anggota komunitas.

Antusias masyarakat dan para pelaku seni (anggota komunitas) sangat besar membuat penyelenggaraan acara pagelaran tersebut secara rutin dilaksanakan, bahkan daya tarik dari acara tersebut dapat menarik perhatian wisatawan domestik maupun mancanegara dan menjadi salah satu pilihan wisata alternatif bagi mereka. Acara yang di adakan di kaki Gunung Manglayang membuat para wisatawan tidak hanya merasa terhibur oleh seni budaya tradisional yang ditampilkan, tetapi para wisatawan juga disuguhkan dengan pemandangan alam sekitar yang masih asri dan sejuk. Berjalan selama empat tahun, tepatnya pada tahun 2014 acara tersebut bertransformasi menjadi "Manglayang Midang S.A.E" dengan tujuan melestarikan seni budaya, alam, dan meningkatkan perekonomi masyarakat sekitar.

Dukungan dari Pemerintahan Kota Bandung membuat Komunitas DAPSENBUD mengantongi legalitas, yang mana legalitas ini diberikan untuk komunitas agar dapat secara leluasa melakukan kegiatankegiatan yang berkaitan dengan pelestarian seni budaya dan membantu dalam perkembangan industri pariwisata yang dipayungi oleh badan hukum. Mendapat kepercayaan dari masyarakat dan Pemerintahan Daerah eksistensi komunitas DAPSENBUD merangkak naik dengan membawa nama daerahnya untuk dikenal oleh daerah lain.

Melalukan pelestarian seni budaya tradisional melalui kegiatan pariwisata menjadi alat utama yang dapat dilakukan sebagaimana yang di kemukakan oleh UNESCO dan UNWTO dalam keputusan bersama mereka di tahun 2002. (Utama, 2014) Dapat diartikan bahwa pariwisata menyembatani pelestarian seni budaya tradisional besamaan dengan membantu ke dalam perkembangan industri pariwisata di sektor kebudayaan. Unsur kebudayaan pun menjadi yang paling diminati dan ingin di ketahui oleh sebagian wisatawan yang datang berkunjung ke daerah Asia dan kawasan Pasific. PATA dalam Pendit (1994, dalam Ardiwidjaja, 2020) Karena memang seni budaya tradisional yang memiliki nilai dan keunikan tersendiri masih dapat memikat dan tidak dapat tergantikan oleh budaya modern.

Mengenai Industri pariwisata di Kota Bandung memegang indeks pariwisata tertinggi di Indonesia melebihi kota-kota pariwisata lainnya menurut perhitungan Frontier Consulting Group dan Tempo Media Group, yakni mencapai $95.30 \%$ yang mana lebih tinggi dari Kota Denpasar dengan indeks pariwisata $87.65 \%$ dan $85.68 \%$ dari Kota 
Yogyakarta. (Pemerintah Provinsi Jawa Barat, 2018)

Tetapi sangat di sayangkan dari pengelelolaan pariwisata yang belum optimal dapat berdampak buruk, seperti terjadinya penurunan jumlah wisatawan mancanegara dan domestik di Kota Bandung pada tahun 2016 sebesar 10\%, yang berpengaruh terhadap penurunan kunjungan kesejumlah objek wisata di Kota Bandung sebesar $60 \%$. (Halim, 2017) Terutama di sektor pariwisata budaya yang masih belum maksimalnya dalam pengembangan industri pariwista dikarenakan terdapat kendala - kendala dan permasalahan seperti akomodasi, sarana, pra sarana, infrastruktur yang belum memadai dan pengelolaannya yang masih lemah membuat Kota Bandung belum bisa unggul di sektor pariwisata kebudayaan. Kota Bandung juga kurang gencar dalam melakukan pemasaran/promosi menjadi permasalahan lain karena tidak dapat memberikan informasi untuk meningkatkan minat para wisatawan.

Tabel 1.Jumlah kunjungan kedestinasi wisata

\begin{tabular}{|l|l|l|l|l|l|}
\hline $\begin{array}{l}\text { Jenis } \\
\text { Wisata }\end{array}$ & 2012 & 2013 & 2014 & 2015 & 2016 \\
\hline $\begin{array}{l}\text { Wisata } \\
\text { Belanja }\end{array}$ & 1.054 .628 & 1.487 .759 & 1.665 .406 & 2.734 .213 & 2.998 .456 \\
\hline $\begin{array}{l}\text { Wisata } \\
\text { Kuliner }\end{array}$ & 2.138 .555 & 2.493 .983 & 3.346 .968 & 3.745 .985 & 3.983 .589 \\
\hline $\begin{array}{l}\text { Wisata } \\
\text { Buatan }\end{array}$ & 679.849 & 701.373 & 745.076 & 870.997 & 1.034 .838 \\
\hline $\begin{array}{l}\text { Wisata } \\
\text { Budaya }\end{array}$ & 304.951 & 309.505 & 347.677 & 389.706 & 414.657 \\
\hline
\end{tabular}

Sumber: Dinas Budaya dan Pariwisata Kota Bandung tahun 2016

Dapat dilihat dari tabel diatas menunjukan bahwa minat kunjungan wisatawan pada wisata budaya sangat minim. Ini disebabkan oleh kendala dan permasalahan yang sudah disampaikan di atas juga beberapa faktor, faktor utama pemerintah yang masih kurang fokus dalam mengembangkan wisata kebudayaan, dan kesadaran masyarakat juga menjadi alasan lain. Kota Bandung yang di kenal kaya akan seni budaya tradisionalnya tampak tidak sesuai dengan kenyataan.

Oleh karena itu hal ini dapat disiasati dengan pembentukan city branding sebagai salah satu cara pembangunan suatu tempat/daerah untuk dipasarkan memalui pariwisata. City Branding merupakan perencanaan sebuah kota untuk membentuk diferensisasi dan memperkuat identitas kota agar memiliki daya saing tinggi dibandingkan dengan kota lain, yang bertujuan untuk menarik wisatawan, investor, industri, dan sumber daya manusia yang kredibel dalam menciptakan kualitas hubungan antara warga dengan kotanya. (Yananda \& Salamah, 2014) City branding dan place marketing berjalan bersamaan, dimana place marketing diperuntukan untuk mengkonstruksi, komunikasi dan pengelolaan citra, sedangkan brading digunakan untuk mengamankan ekonomi, pembentukan identitas kota, pengembangan komunitas, melibatkan para sipil dan hubungan yang erat. Kavaratzis (2004, dalam Yananda \& Salamah, 2014)

Kota Bandung mentapkan brand 'Stunning Bandung" yang memiliki arti pintu utama pariwisata Jawa Barat yang merupakan sub-brand dari "Wonderful Indonesia". (Wisatabdg.com, 2017) Masih dirasa belum berhasil disektor wisata budaya maka Pemerintahan Daerah Dinas Budaya dan Pawirisata Kota Bandung melakukan perancangan visi dan misi dalam Pembangunan Jangka Menengah Daerah (RPJMD) secara khusus mengenai urusan kebudayaan dan pariwisata. Visi menargetkan Kota Bandung sebagai Kota Seni Budaya dan tujuan Wisata Internasional dengan Misi meningkatkan pelestarian seni dan budaya, pemberdayaan, dengan terus melakukan pengembangan, dan selanjutnya pemanfaatan kesenian dan budaya, juga peningkatkan destinasi-destinasi pariwisata Kota Bandung yang berdaya saing tinggi baik pada tingkat regional, nasional maupun internasional. Seni dan budaya tradisional yang dilestarikan, adalah sebagai upaya perlindungan, pengembangan, dan pemanfaatan kesenian untuk kesejahteraan masyarakat, kebanggaan nasional dan memperkuat identitas bangsa. (PPID, 2018)

Pembentukan citra memerlukan penetapan identitas terlebih dahulu. Citra terbentuk biasanya pada pandangan pertama seseorang dan bagaimana seseorang tersebut menarik kesimpulan dari informasi yang di komunikasikan yang menimbulkan persepsi/gambaran yang melekat. Persepsi/gambaran setiap orang berbeda-beda hal tersebut dipengaruhi menurut hasil pengalaman, pengetahuan, dan pengamatan yang menghasilkan respon seseorang. Biasanya citra terbentuk tidak sesuai dengan 
yang diharapkan dan bahkan dapat dikatakan buruk, karena kurangnya pengelolaan identitas sebelumnya.

Oleh karena itu Kota Bandung mencoba untuk memperkuat identitas kota sebagai Kota Seni Budaya, sebagai upaya membangun citra dimata khalayak bahwa Kota Bandung masih kuat akan seni budaya tradisionalnya. Kota Bandung dapat dikatakan kaya akan citranya yang tergolong kedalam star model, tapi sayang Kota Bandung dirasa masih belum mempunyai citra yang menonjol. Pratikno (2007, dalam Fatmala, 2019) city branding adalah sebuah proses pengenalan sebuah kota yang diwakilkan pada sesuatu yang dapat memproyeksikan kota tersebut seperti pemilihan duta, ikon atau penyelenggaraan event, sehingga kota tersebut memiliki keunikan dan keunggulan tersendiri dari kota lainnya yang membuat kota tersebut terkenal. Dengan melakukan kerja sama dengan para pemangku kepentingan untuk berpartisipasi kedalam tujuan yang sudah direncanakan agar dapat terwujudkan dan melakukan sinegritas kepada komunitas-komunitas terutama komunitas seni budaya sebagai perwakilan sebuah ikon yang menggambarkan Kota Bandung sebagai Kota Seni Budaya contohnya, diharapkan dapat menghasilkan citra Kota Bandung yang dominan.

Berdasarkan pendahuluan di atas membuat peneliti tertarik untuk mengetahui bagaimana upaya Komunitas DAPSENBUD sebagai ikon Seni Budaya Kota Bandung. Dengan tujuan untuk mengetahui apa saja peran Komunitas DAPSENBUD sebagai ikon dalam membantu pembentukan city branding Kota Bandung dengan pemanfaatan seni dan budaya yang mereka lestarikan melalui pariwisata agar tetap eksis dan dikenal oleh semua orang.

\section{Tinjauan Pustaka}

\section{A. City Branding}

Miller Merrilees dan Herington (2009, dalam Megantari, 2019) mengatakan bahwa City Branding adalah sebuah saluran berkomunikasi yang pas untuk membangun brand suatu negara, kota, daerah, ataupun masyarakat yang ada di dalamnya berdasarkan wujud mereka. City branding merupakan bagian dari brand tempat yang ditetapkan untuk satu kota atau keseluruhan wilayah sebuah negara.

Paraktik City Branding dilakukan untuk menarik wisatawan, dengan pengertian lain Destination branding merupakan bagian lain dari city branding. Destination branding diberlakukan untuk menjual pariwisata, dengan maksud untuk menarik wisatawan berkunjung ke tujuan tertentu. City Branding diasumsikan sebagai cara untuk mencapai benefit yang kompetitif dalam bidang pariwisata namun juga bisa digunakan untuk membangun komunitas, memperkuat identitas lokal dan memperkenalkan warga terhadap kekayaan yang dimiliki kotanya sendiri dalam upaya menghidupkan seluruh kekuatan sosial. (Megantari, 2019)

Simon Anholt (2006, dalam Megantari, 2019) juga menegaskan bahwa City Branding adalah upaya pemerintah untuk membentuk identitas tempat, atau suatu wilayah yang kemudian memasarkannya kepada klayak, baik secara internal maupun eksternal.

Hankinson (2007, dalam Megantari, 2019) mengemukakan bahwa City Branding erat kaitannya dengan faktor bagaimana kepemimpinan kepala daerah menglola kotanya, dengan budaya organisasi yang berorientasi pada brand, pengkoordinasian departemen yang berbeda akan membentuk citra brand yang dipasarkan. Kegiatan komunikasi yang intens dan konsisten, menjadi hal wajib yang perlu dilakukan pemerintah kota untuk terjalinnya hubungan yang saling menguntungkan dengan para stakeholder yang terkait melalui menjalin kemitraan yang kuat dan dapat dipercaya.

Dalam konsep City Branding menuntut terjalinnya sinergitas dari keseluruhan unsur pembentuk kota, seperti aspek SDM, fasilitas sosial, fasilitas umum maupun pengelolaan transportasi yang saling berhubung. Tidak adanya sinergitas yang terjalin baik, upaya pembentukan City Branding akan percuma, oleh karena itu fungsinya tidak hanya perihal komunikasi pemasaran kota secara publik, tetapi dapat juga mendukung dalam strategi pengembangan seni dan budaya, pariwisata, kawasan industri dan perdagangan. Hasil dari itu semua akan berdampak kepada meningkatkannya perekonomian masyarakat kota yang dipasarkan tersebut maka 
kesejahteraan dari masyarakat juga semakin meninggkat. (Putra, 2015)

Pratikno (2007, dalam Fatmala, 2019) mendefinisikan City Branding sebagai sebuah proses pengenalan sebuah kota yang diwakilkan pada ikon, duta atau acara yang diselenggarakan di kota yang bersangkutan sehingga kota tersebut akan dikenal sebagai kota yang unik dan lain dari kota lain.

Perspektifkan ikon menurut Moser (2006, dalam Sukmaraga \& Nirwana, 2016), secara harfiah terkait dengan indera penglihatan, sesuatu yang unik bagi merek, dan sebagai sesuatu yang dapat memberikan gambaran tentang merek. Terdapat beberapa jenis Ikon menurut Moser diantaranya: (1) Ikon suara (Sulih suara, musik, mnemonik), (3) Ikon rasa (desain dan bentuk, tekstur, suhu), (2) Ikon visual (Logo, produk/kemasan, warna, tipografi, desain dan layout, teknik visual, arsitektural unik), (4) Ikon sentuhan, dan (5). Ikon aroma

Peirce berpendapat dalam terminologinya, bahwa ikon merupakan sebuah tanda yang berlandaskan atas "keserupaan" atau kesamaan antara representamen dan obyeknya, tetapi tidak seolah-olah mencakup tentang citra-citra "realistis" seperti pada lukisan atau foto, melainkan suatu gambaran seperti skema, grafik-grafik, persamaan matematis, metafora ataupun peta geografis. (Budiman 2011, dalam Sukmaraga \& Nirwana, 2016).

\section{B. Industri Pariwisata Kota Bandung}

Bicara tentang Kota Bandung yang memiliki nama lain Kota Kembang, merupakan Ibu Kota dari Jawa Barat. Sejarah dari peninggalan-peninggalan pada jaman penjajahan menghiasi beberapa sudut kota yang meninggalkan kenangan. Penduduk dari Kota Bandung didominasi oleh etnis sunda yang dikenal ramah, menjadi salah satu alasan mengapa Kota Bandung sangat kental akan seni dan budaya tradisional sunda. Potensi lain dari Kota Bandung berada di

industri pariwisata, menyuguhkan berbagai macam destinasi wisata, dimana wisatawan dapat memilih wisata yang mereka sukai diantaranya seperti, wisata busana, wisata kuliner, budaya, alam dan masih banyak lagi, yang dapat memanjakan para wisatawan domestik maupun mancanegara yang berkunjung. Letak geografis yang baik, udara yang masih cukup sejuk, menunjang Kota
Bandung memiliki pesona tersendiri dan menjadi salah satu kota idaman. Hal ini yang membuat Kota Bandung bisa dibilang lebih unggul dibandingkan kota-kota lain yang ada di Jawa Barat. Bahkan pada tahun 2014 Kota Bandung mampu menduduki posisi ke 21 sebagai destinasi wisata terpopuler/terfavorit didunia menurut hasil survei yang dilakukan oleh situs Fastbooking.com. (Tribun Jabar.id, 2014)

Pariwisata di kota bandung dapat menyumbang $33 \%$ yang berasal dari aktivitas pariwisata, pajak hotel, hiburan, hingga restoran kedalam Pendapatan Asli Daerah (PAD) atau sekitar 740 miliar rupiah. Pada tahun 2018 Kota Bandung dikunjungi 7,5 juta wisatawan domestik dan 155 ribu wisatawan mancanegara yang berkunjung dengan mengeluarkan uang rata-rata 1 juta rupiah per orang. (Andriyawan, 2019)

Table 2. Wilayah Tujuan Wisata di Kota Bandung

\begin{tabular}{|c|c|c|c|}
\hline No & Area Destinasi & Tema & Aktifites \\
\hline 1 & $\begin{array}{l}\text { Alum-alum, } \\
\text { Sudirman, Otiste, } \\
\text { Gardujati }\end{array}$ & $\begin{array}{l}\text { Berbelanja } \\
\text { pakzian, } \\
\text { Bahan balas } \\
\text { pabrik, } \\
\text { Jalan-jalan. }\end{array}$ & $\begin{array}{l}\text { Wisata Belanja, } \\
\text { Wisata Heritage }\end{array}$ \\
\hline 2 & $\begin{array}{l}\text { Dago Utara, } \\
\text { Punclut }\end{array}$ & Kuliner & Wisata Kuliner \\
\hline 3 & $\begin{array}{c}\text { Dago, Merdelca, } \\
\text { Riau }\end{array}$ & Berbelanja & $\begin{array}{l}\text { Wisata Belanja, } \\
\text { Wisata Heritage }\end{array}$ \\
\hline 4 & $\begin{array}{l}\text { Sukzjadi, Sarijadi, } \\
\text { Setrasari, Pasteur }\end{array}$ & Berbelanja & $\begin{array}{c}\text { Thisata } \\
\text { Berbelanja }\end{array}$ \\
\hline 5 & Cibaduyut & Berbelanja & Wisata Belanja \\
\hline 6 & $\begin{array}{l}\text { Geger Kalong. } \\
\text { Setiabudhi }\end{array}$ & $\begin{array}{l}\text { Berbelanja } \\
\text { Pakaian, } \\
\text { Kuliner }\end{array}$ & $\begin{array}{c}\text { Wisata } \\
\text { Pendidikan }\end{array}$ \\
\hline 7 & $\begin{array}{l}\text { Cihampelas, } \\
\text { Cipaganti }\end{array}$ & Berbelanja & $\begin{array}{c}\text { TWisata } \\
\text { Berbelanja. } \\
\text { Wisata Kuliner }\end{array}$ \\
\hline 8 & $\begin{array}{l}\text { Gedung Sate, } \\
\text { Gasibu, Sabuga }\end{array}$ & $\begin{array}{l}\text { Museum, } \\
\text { Jalan-jalan }\end{array}$ & $\begin{array}{c}\text { Wisata Heritage, } \\
\text { Wisata } \\
\text { Pendidilkan }\end{array}$ \\
\hline 9 & Tegalega & Rekreasi & $\begin{array}{l}\text { Wisata Alam dam } \\
\text { hiburan }\end{array}$ \\
\hline 10 & $\begin{array}{l}\text { Braga, Asia- } \\
\text { Afrika, } \\
\text { Cikapundung }\end{array}$ & $\begin{array}{l}\text { Gedung } \\
\text { peninggalan } \\
\text { Belanda }\end{array}$ & Wisata Heritage \\
\hline II & Suci, Podasuka & Konvelcai & Wisata Belanja \\
\hline 12 & Gatot Subroto & $\begin{array}{l}\text { Berbelanja, } \\
\text { Rekreasi }\end{array}$ & $\begin{array}{l}\text { Wisata Belanja, } \\
\text { Wisata Hiburan }\end{array}$ \\
\hline 13 & $\begin{array}{c}\text { Ujung Berung } \\
\text { Cibiru }\end{array}$ & Rekreasi & $\begin{array}{c}\text { Wisata seni dan } \\
\text { budaya }\end{array}$ \\
\hline 14 & Cigonewah & $\begin{array}{l}\text { Komplek } \\
\text { Inchustri }\end{array}$ & Wisata \\
\hline 15 & Gedebage & Berbelanja & Wisata belanja \\
\hline
\end{tabular}

Sumber: (Windarti, 2016)

Tabel diatas menunjukan beberapa tempat popular yang biasanya dikunjungi oleh para wisatan domestik maupun mancanegara. Tetapi Bandung masih memiliki banyak destinasi pariwisata lain yang bisa para wisatawan jelajah lebih jauh. 


\section{Metodologi Penelitian}

Penelitian ini menggunakan metode kualitatif sebagai cara untuk menemukan sebuah makna, menyelidiki suatu proses, agar memperoleh pengertian dan pemahaman yang mendalam. Selain itu penelitian ini juga menggunakan pendekatan studi kasus, dimana kasusnya dapat berupa organisasi, komunitas, peristiwa, isu dan sebagainya atau secara umumnya merujuk kesebuah lokasi. Maka pemilihan metode ini dirasa tepat karena peneliti mengkaji proses upaya sebuah komunitas seni dan budaya (DAPSENBUD) sebagai ikon seni budaya kota Bandung. Pengumpulan data dilakukan melalui wawancara mendalam untuk mendapatkan informasi yang relevan dari informan terkait diantaranya: Pemerintahan Daerah Dinas Budaya dan Pariwisata Kota Bandung, Ketua Komunitas DAPSEMBUD, dan anggota aktif Komunitas DAPSENBUD, juga menggunakan kajian litelatur terdahulu yang meneliti tentang pembentukan city branding. Teknik analisis data dalam penelitian ini menggunakan teknik menurut Miles dan Huberman (dalam, Ardianto, 2010) yang mana analisis ini dibagi menjadi tiga tahapan yaitu (1) Reduksi data; (2) Penyajian data; dan (3) Penarikan kesimpulan dan melakukan verifikasi..

\section{Hasil dan Diskusi}

Bagian ini Kiat city branding di Kota Bandung terus dilakukan sejak tahun 2013 oleh Ridwan Kamil yang saat itu menduduki sebagai Walikota. (Maulana \& Herlily, 2015) Kota Bandung yang kaya akan potensi alam, budaya, wisata dan lainnya menjadi suatu alasan mengapa pembentukan city branding diperlukan, selain sebagai pembentukan identitas untuk menghasilkan sebuah citra, city branding juga diharapkan dapat menjadi acuan pembangunan sebuah kota.

Kota Bandung menetapkan brand "Stunning Bandung" pada tahun 2016 dengan panggilan lain "memesona" diharapkan dapat melekatkan sebuah kesan yang positif dan mudah untuk kenang oleh para masyarakat domestik maupun mancanegara. Stunning Bandung: Where the Woders of West Java Begin memiliki artian sebagai pintu utama pariwisata Jawa Barat yang merupakan yang diselaraskan dengan master-brand "Wonderful Indonesia" agar tercipta sinergi brand pusat dengan brand daerah. (Wisatabdg.com, 2017)

\section{Upaya Komunitas DAPSENBUD sebagai Ikon Seni Budaya Kota Bandung}

Pembentukan city branding yang melibatkan banyak pihak untuk berperan seperti Pemerintah, para investor, pemegang industri pariwisata, ataupun masyarakat, membuat keberhasilan city branding dapat terjadi. Peran masyarakat yang berpartisipasi mendukung kedalam pembentukan city branding menunjukkan bahwa orientasi mereka menjadi bagian penting untuk pembentukan suatu brand sebuah tempat. Oleh karena itu keterlibatan mereka dirasa penting untuk dipikirkan dalam membranding kota. (Braun, Kavaratzis, \& Zenker, 2013)

Kehadiran Komunitas DAPSENBUD yang terbentuk dari kelompok masyarakat yang berupaya mendapatkan kesejajaran dalam memperoleh hak-haknya untuk beradaptasi dari perubahan sosial yang terjadi dan mewujudkan tujuan bersama, berkumpul dalam satu wadah komunitas. Memiliki latar belakang yang sama sebagai para pelaku seni, Komunitas DAPSENBUD melakukan kegiatan-kegiatan pemanfaatan seni dan budaya tradisional melalui pariwisata untuk meningkatkan perekonomian para pelaku seni dan masyarakat sekitar.

Melihat potensi dari kawasan Sentra Terpadu Manglayang atau Pasar 46, yang biasanya disetiap hari minggu dipenuhi oleh masyarakat lokal untuk melakukan olahraga, dan berbelanja. Komunitas DAPSENBUD mengadakan suatu acara pagelaran "Pentas Seni budaya" untuk menghibur sekaligus memperkenalkan seni budaya tradisional yang ada di daerah Cibiru, dari hasil inisiatif para anggota melakukan patungan/iuran. Karena mereka tidak terbentuk dari arahan pemerintah melainkan keinginan mereka sendiri, membuat komunitas DAPSENBUD independen dan saling gotong-royong.

Kegiatan acara-acara yang bertujuan mengkomunikasikan kepada masyarakat pemperlihatkan kreativitas yang dimiliki oleh seluruh warga, dalam upaya melakukan tahap selanjutnya dalam membentuk city branding. Dan didalam proses melakukan komunikasi harus memiliki kesamaan dan peran dari semua pihak, seperi pemerintah, komunitas- 
komunitas, dan pelaku UKM. (Setiawati, Suryana, Sugiana, \& Priyatna, 2020)

Terlihat semangat dari masyarakat dan para pelaku seni setelah diadakan acara tersebut cukup besar, dan seiring berjalannya waktu acara tersebut terus didatangi oleh wisatawan baru. Selama empat tahun melakukan acara pagelaran "Pentas Seni Budaya" akhirnya komunitas DAPSENBUD mendapatkan kepercayaan juga perhatian dari Pemerintah Daeraha untuk membuat acara pagelaran mereka menjadi lebih besar yang diberi nama "Manglayang Midang". Komunitas DAPSENBUD juga memiliki beberapa event lain seperti Hajat Budaya, Festival Reak Bandung dan sebagainya, bertujuan agar semua anggota Komunitas DAPSENBUD yang terdiri dari berbagai macam kelompok/grup seni budaya dapat secara rata dipertunjukan.

Ridwan Kamil saat menjabatan sebagai Walikota mengatakan pertunjukan seni budaya dapat menarik wisatawan dan menjadi keunggulan Kota Bandung sesuai dengan yang direncanakan dalam strategi branding destinasi pemerintah Kota Bandung, menjadikan event budaya sebagai magnet pariwisata. (City Branding Indonesia's Leading MarComm Media, 2018)

Acara manglayang midang merupakan acara unggulan dari komunitas DAPSENBUD, acara yang diadakan dua kali dalam satu tahun ini selalu dipenuhi oleh kunjungan wisatawan domestik maupun mancanega yang ingin melihat pertunjukan mereka. Acara yang diadakan di kaki gunung malayang menjadi alasan lain mengapa acara ini sangat unik, dapat melihat indahanya pemandangan Kota Bandung dari ketinggian, dan wisatawan juga dapat melakukan wisata kuliner yang di jajakan oleh masyarakat sekitar untuk membantu memeriahkan acara yang di selenggarakan.

Pembentukan city branding merupakan strategi komunikasi untuk memperkenalkan suatu daerah melalui merek, slogan, simbol, ikon ataupun identitas sebagai perwakilan yang merupakan bagian dari daerah tersebut. (Kamil, 2017) Komunitas DAPSENBUD beberapa kali berangkat ke kota-kota di Indonesia mewakili Kota Bandung untuk menjadi duta Kota Bandung diantaranya Kota Dumai pada tahun 2014, Kota Bali, dan beberapa kota di Jawa Barat seperti Kota Purwakarta. Dan hal tersebut merupakan strategi yang dilakukan Pemerintah Daerah Kota Bandung dalam pembentukan city branding untuk membuat positioning yang kuat di dalam benak target mereka.(Astuti, 2017)

Pemerintahan Daerah juga selalu mengikut sertakan komunitas DAPSENBUD kedalam kegiatan-kegiatan berupa pembinaan untuk perkembangan seni budaya tradisional dan melibatkan Komunitas DAPSENBUD pada acara-acara yang di adakan oleh Pemerintah Daerah seperti pada acara Asia Afrika Karnaval, komunitas DAPSENBUD mengirimkan 25 gagak layang untuk acara terebut.

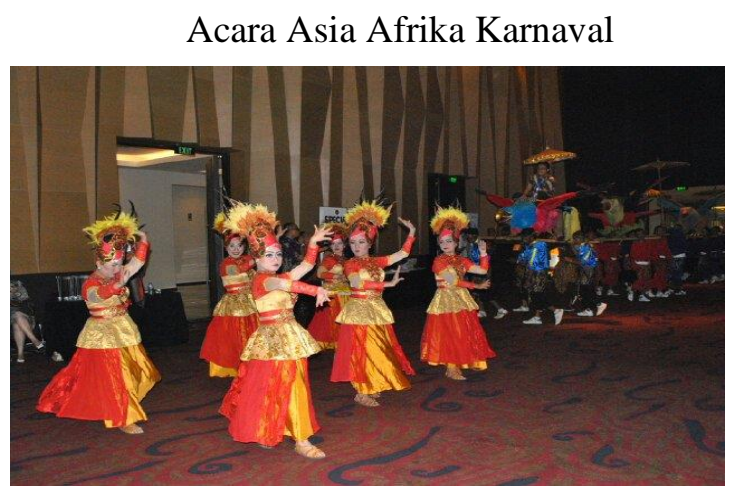

Sumber: Dokumentasi DAPSENBUD

Kota Bandung yang ingin menjadi Kota seni budaya dan tujuan wisata internasional sebagai pendukung pembentukan suatu brand yang dilakukan oleh Kota Bandung sudah disesuaikan dengan potensi dan keunikan yang dimiliki, yang diputuskan oleh Pemerintahan Daerah sebagai pembuat regulasi. Hasil dari penetapan identitas/brand menciptakan awareness, dan citra yang membentuk persepsi baik mengenai daerah tersebut. (Kamil, 2017)

Dengan keberadaan Komunitas
DAPSENBUD yang sangat baik membuktikan bahwa mereka layak untuk menjadi salah satu Ikon yang menggambarkan Kota Bandung dalam membangun citra positif dan mempertkuat identitas. Disaat orangorang mendengar daera Bandung Timur tepatnya daerah Cibiru, mereka akan mengetahui bahwa ada sebuah komunitas seni budaya tradisional (DAPSENBUD) yang melakukan pelestarian melalui pariwisata dengan acara-acara pagelaran yang mereka miliki yang termasuk kedalam deferensiasi yang mereka bentuk untuk membedakan mereka lebih unggul dibandingkan dengan 
daerah lain. Ikonik dari daerah Cibiru salah satunya kesenian budaya tradisional yang ada di komunitas DAPSENBUD sendiri diantaranya adalah Reak dan Gagak layang, bahkan kesenian gagak layang diberikan nama khusus oleh Ridwan Kamil saat menduduki sebagai Walikota Bandung menjadi Angry Bird Bandung (ABB).

Kavaratzis (2004, dalam Astuti, 2017) mengemukakan komunikasi citra merupakan bagian pembentuk city branding yang memiliki tiga bagian komunikasi yaitu: (1) komunikasi primer merupakan segala bentuk bagian dari kota, seperti : birokrasi, infrastruktur, strategi landscape, perilaku atau tindakan yang berkaitan dengan kota tersebut.

(2) komunikasi sekunder adalah komunikasi formal, yang mana komunikasi pemasaran memang dibuat oleh si pemasar sesuai dengan konsep, tujuan dan maksud, seperti kehumasan, desain grafis, iklan dan sebagainya. (3) komunikasi tersier merupakan komunikasi secara luas dengan menggunakan media internet, yang informasinya tidak bisa dikendalikan oleh pemasar.

Cara Komunitas DAPSENBUD melakukan strategi komunikasi dalam mempromosikan sedikit berbeda dengan yang lainnya. Komunitas DAPSENBUD berupaya untuk memasarkan seni budaya tradisional secara nyata, sebagai pembuktian bahwa mereka memang ada. Tidak hanya berkesenian tetapi mereka juga ingin bisa membantu masyarakat sekitar. Seperti mereka pergi kebeberapa sekolah untuk memberikan penyuluhan tentang seni budaya teradisional, dan biasanya meminta untuk menjadikan seni budaya tradisional sebagai ekstra kulikuler yang benar-benar diterapkan tidak hanya sebatas pelajaran. Melakukan kegiatan kegiatan sosial seperti pembagian takjil gratis, donasi para seniman yang terkena dampak pandemi Covid-19 dan promosi secara umum/luas juga mereka lakukan seperti bekerja sama dengan perusahaan media, penyebaran brosur, penerapan spanduk atau baligo, media sosial youtube, facebook, instagram dan sebagainya tetapi memang komunikasi tersier kurang efektif kesenian budaya dirasa kehilangan peminatnya di media sosial.

Kegiatan-kegiatan yang mereka lakukan sebenarnya bertujuan kepada pelestarian seni dan budaya tradisional. Kecintaan mereka terhadap seni dan budaya tradisional membuat mereka melakukan upaya - upaya agar seni dan budaya tradisional dapat kembali diminati. Komunitas DAPSENBUD secara suka rela melakukan pelestarian seni budaya tradisional sesuai dengan tujuan terbentuknya komunitas juga mencoba untuk mengimplementasikan Peraturan Daerah Kota Bandung Nomor 05 tahun 2012 tentang pelestarian seni budaya tradisional. (DPRD Kota Bandung, 2012) Berlanjut dengan terbitan Peraturan Walikota Bandung Nomor 059 tahun 2013 sebagai petunjuk pelaksanaan untuk melakukan pelestarian seni tradisional diantaranya : (1) Pelindungan Seni Tradisional; Pengembangan Seni Tradisional; dan (3) Pemanfaatan Seni Tradisional. Pemanfaatan seni budaya tradisional disini diperuntukan sebagai bahan ajar, pelaksanaan pagelaran kesenian, pengembangan wisata dan sebagainya. (Walikota Bandung, 2013) sebagai pedoman mereka. Berharap hasil dari berkesenian dapat menjadi profesi yang bisa dibanggakan dan mampu meningkatkan perekonomian para anggotanya.

$$
\text { Pengembangan seni budaya }
$$

tradisional komunitas DAPSENBUD selalu coba lakukan dengan melakukan inovasiinovasi kreatif agar seni budaya tradisional dapat diterima oleh semua kalangan. Sebagian dari anggota komunitas DAPSENBUD merupakan para generasi muda. Ini menjadi alat utama komunitas DAPSENBUD menumbuhkan kembali minat para generasi muda sebagai ujung tombak pelestarian.

\section{Proses latihan komunitas DAPSENBUD}

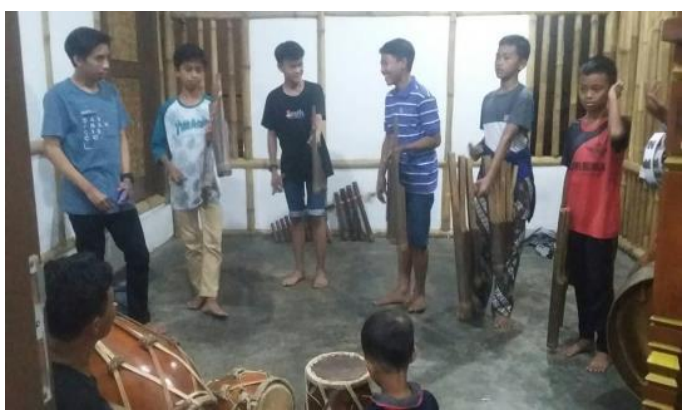

Sumber: Dokumen DAPSENBUD

Untuk tugas sebagai anggota Komunitas DAPSEBUD diantaranya harus tertib organisasi, tertib administrasi, dan tertib oprasional. Tugas lainnya sebagai anggota komunitas DAPSENBUD adalah pembinaan untuk pelatihan yang diserahkan sepenuhnya 
kepada anggota masing-masing, karena memang masih belum adanya sarana, pra sarana untuk dapat melakukan latihan bersama, mengingat juga jumlah anggota yang kurang lebih mencapai 80 kelompok/grup dengan 5000 pelaku seni, memerlukan lahan/tempat yang sangat besar jika dilakukan latihan secara bersama. Maka dari itu komunitas DAPSENBUD meminta para anggotanya untuk melakukan di sanggar/tempat masing-masing, tetapi masih di bawah pengawasan komunitas DAPSENBUD. Para pengurus komunitas DAPSENBUD secara bergilir akan berkunjung untuk melihat perkembangan dari hasil latihan rutin yang sudah mereka lakukan agar memenuhi kriteria layak tampil, layak tonton dan layak jual.

\section{Dukungan pemerintah pada komunitas DAPSENBUD}

Dukungan yang diberikan oleh Pemerintahan Daerah terutama Dinas Budaya dan Pariwisata Kota Bandung diantaranya seperti pemberian legalitas bagi komunitas DAPSENBUD untuk dapat payung hukum dalam kegiatan-kegiatan yang mereka lakukan.

Pemeritahan Daerah pun memberikan pembinaan bagi komunitas DAPSENBUD untuk mendapatkan pembelajaran seperti diikut sertakan dalam kegiatan-kegiatan studi banding, penyuluhan tujuan Pemerintahan Daerah mengenai perkembangan seni budaya dan sebagainya.

Pemerintahan Daerah juga memberikan dana pembinaan bagi Komunitas DAPSENBUD agar selalu berinovasi dan semakin kreatif untuk mengembangkan seni budaya tradisional agar dapat mencapai target menjadi seni budaya internasional. Melibatkan komunitas DAPSENBUD kedalam acara-acara yang diselenggarakan oleh Pemerintah Daerah seperti acara Rakernas APEKSI, Asia Afrika Karnaval, menjadi perwakilan Kota Bandung dan lainlain.

Pemerintahan Daerah Dinas Budaya dan Pariwisata juga membuat program BARATA (Bandung Rasa Nyata) dimana seni dan budaya tradisioanal di berdayakan untuk ditambilkan di bandara-bandara, hotel, Car free days dan lainnya dengan tujuan agar seni budaya tradisional dapat benar terasa oleh masyarakat. (SM, 2018)
Pemerintahan Daerah juga membuat target indikator sasaran Rencana Pembangunan Jangka Panjang Daerah (RPJMD) 2013-2018 urusan kebudayaan dan pariwisata. Pemerintahan Daerah berupaya mewujudkan pembangunnan pusat-pusat kebudayaan sebagai sarana pelestarian seni dan budaya, meningkatkan sinergitas pelestarian seni dan budaya lokal dengan pemerintah, pelaku budaya juga masyarakat. Dan melakukan pelaksanakan pelayanan yang berkaitan dengan kepariwisataan melalui fasilitasi investasi dan promosi pariwisata, kerjasama dengan mitra pariwisata, memfasilitasi kegiatan atau event kepariwisataan, juga pemberian pembinaan tentang pengelolaan sarana wisata dan obyek wisata. (PPID, 2018)

Beberapa sudah ter-implementasikan seperti pembangunan tempat seni budaya di daerah Cibiru "Teras Sunda" sebagai wadah bagi para seniman yang ingin melakukan kegiatan kesenian budaya disana dan menjalin sinergritas dengan para pelaku seni salah satunya Komunitas DAPSENBUD.

\section{Kesimpulan}

Kecintaan pada seni dan budaya tradisional Komunitas DAPSENBUD melakukan pelestarian melalui pariwisata yang ternyata juga dapat membantu kedalam perkembagan industri pariwisata. Acara yang mereka buat dapat berhasil menarik minat berkunjung wisatawan domestik maupun mancanegara, yang setidaknya dapat membantu membuka peluang bagi masyarakat sekitar agar dapat berpartisipasi mensukseskan acara yang komunitas DAPSENBUD adakan dengan memanfaatkan moment untuk mendapatkan penghasilan.

Meski memang kenyataanya wisata budaya hanya sebatas membangun rasa ketertarikan saja, karena keunikan yang dimiliki, yang membuat seni dan budaya tradisional kurang menjanjikan yang membuat tidak bisa menjadi sumber pendapatan utama, tetapi bukan dalam artian menjadi wisata pilihan terakhir.

Upaya mereka untuk menjadi Ikon Seni Budaya yang dibentuk melalui pembentukan ciri khas sebagai diferensiasi dalam kesenian budaya tradisional yang lahir dari tempat mereka dan membawa seni budaya tradisional yang ada di Kota Bandung ke beberapa kota luar Provinsi. Kegiatan-kegiatan diluar pelestarian komunitas DAPSENBUD lakukan 
membantu membentuk citra Kota Bandung yang positif, peduli akan lingkungan sekitar dan mempertahankan citra Kota Bandung yang kaya akan seni budaya.

Dukungan dari pemerintah daerah pun tidak bisa terelakan karena memang Pemerintah Daerah memiliki tanggung jawab yang tinggi dalam pelestarian seni budaya tradisional sekaligus praktik perkembangan industri pariwisata. Meskipun masih dianggap kurang maksimal karena terkadang disetiap pergeseran jabatan akan merubah fokus awal yang sudah pejabat sebelumnya bangun, yang berpengaruh kepada jangka waktu yang panjang untuk mewujudkan satu tujuan.

\section{References}

[1] Andriyawan, D. (2019). Sektor Pariwisata Sumbang 33\% PAD Kota Bandung. Retrieved June 17, 2020, from www.bandung.bisnis.com website: https://bandung.bisnis.com/read/20191112/5 49/1169479/sektor-pariwisata-sumbang-33pad-kota-bandung

[2] Ardianto, E. (2010). Metode Penelitian untuk Public Relations Kuantitatif dan Kualitatif (1st ed.). Bandung: Simbiosa Rekatama Media.

[3] Astuti, M. T. (2017). Strategi Komunikasi Kota Bandung Dalam Membentuk City Branding Sebagai Destinasi Wisata Belanja. Jurnal Kepariwisataan Indonesia, 12, 111128.

[4] Braun, E., Kavaratzis, M., \& Zenker, S. (2013). My city - my brand: The different roles of residents in place branding. Journal of Place Management and Development, 6(1), $18-28$. https://doi.org/10.1108/17538331311306087

[5] City Branding Indonesia's Leading MarComm Media. (2018). Slogan "Stunning Bandung" untuk Gaet Wisatawan. Retrieved June 30, 2020, from ww.mix.co.id website: http://mix.co.id/citybranding/thestory-of-cities/slogan-stunning-bandunguntuk-gaet-wisatawan

[6] DPRD Kota Bandung. (2012). Peraturan Daerah Kota Bandung Nomor 05 Tahun 2012 Tentang Pelestarian Seni Tradisional. Retrieved June 29, 2020, from https://www.disbudpar.bandung.go.id/ website: https://www.disbudpar.bandung.go.id/asset/ data_regulation/5_2012_PELESTARIAN_S ENI_TRADISIONAL.pdf

[7] Fatmala, D. (2019). City Branding Kota Bandung. Retrieved June 10, 2020, from www.slideplayer.info website: https://slideplayer.info/slide/14229487/
[8] Kamil, S. U. R. (2017). City Branding Sebagai Strategi Komunikasi Pariwisata Kabupaten Buton Tengah. MetaCommunication, 2(1).

[9] Maulana, Y., \& Herlily. (2015). Bandung Juara: Komunitas Kreatif \& City Branding.

[10] Megantari, K. (2019). Penerapan Strategi City Branding Kabupaten Ponorogo "Ethnic Art of Java." Aristo. https://doi.org/10.24269/ars.v7i1.1385

[11] PPID, K. B. (2018). Rencana Strategis Dinas Kebudayaan dan Pariwisata Kota Bandung. 59. Retrieved from https://ppid.bandung.go.id/knowledgebase/re ncana-strategis-disbudpar-tahun-2013-2018/

[12] Putra, H. S. (2015). Pengaruh Event Marketing Terhadap City Branding Kota Bandung. Universitas Pendidikan Indonesia.

[13] Setiawati, S. D., Suryana, A., Sugiana, D., \& Priyatna, C. C. (2020). Pendekatan Triple Helix dalam Membentuk City Branding. ALTASIA, 2(2), 177-185.

[14] SM, T. (2018). Program Barata Hidupkan Seni Budaya, 80 Persen Lingkung Seni di Kota Bandung Terberdayakan. Retrieved June $\quad 30, \quad 2020, \quad$ from www.jabar.tribunnews.com website: https://jabar.tribunnews.com/2018/11/27/pro gram-barata-hidupkan-seni-budaya-80persen-lingkung-seni-di-kota-bandungterberdayakan

[15] Sukmaraga, A. A., \& Nirwana, A. (2016). City Branding: Sebuah Tinjauan Metodologis Dengan Pendekatan Elaboratif, Praktis, dan Ilmiah. Jadecs.

[16] Tribun Jabar.id. (2014). Bandung Ranking ke-21 Tujuan Wisata Terfavorit Dunia. Retrieved June 17, 2020, from www.jabar.tribunnews.com website: https://jabar.tribunnews.com/2014/11/26/ban dung-ranking-ke-21-tujuan-wisataterfavorit-dunia

[17] Walikota Bandung. (2013). Peratuan Walikota Bandung Nomor: 059 Tahun 2013 Tentang Petunjuk Pelaksanaan Peraturan Daerah Kota Bandung Nomor 05 Tahun 2012 Tentang Pelestarian Seni Tradisional. Www.Disbudpar.Bandung.Go.Id.

[18] Wisatabdg.com. (2017). Stunning Banung: Where the Woders of West Java Begin. Retrieved June 30, 2020, from www.wisatabdg.com website: https://www.wisatabdg.com/2017/06/stunnin g-bandung-where-wonders-of-west.html

[20] Yananda, M. R., \& Salamah, U. (2014). Branding Tempat (membangung kota, kabupaten dan provinsi berbasis identitas). Jakarta: Makna Informasi. 
BIODATA PENULIS

Pupung Zulyan, lahir di Bandung tanggal 05 juli 1995, masih berkuliah di kampus Ars University Bandung mengambil jurusan komunikasi, yang sedang menyelesaikan Strata $1 / \mathrm{S} 1$.

No hp: 081293300028

Emil: Zulyan6@gmail.com 